\title{
Tillage methods and mulch on water saving and yield of spring maize in Chitwan
}

\author{
${ }^{1}$ Ishwari Prasad Upadhyay ${ }^{*},{ }^{2}$ Shiva Kumar Jha, ${ }^{3}$ Tika Bahadur Karki, ${ }^{2}$ Jitendra \\ Yadav, ${ }^{2}$ Balram Bhandari \\ ${ }^{1}$ Agricultural Engineering Division, Khumaltar, Lalitpur \\ ${ }^{2}$ National Maize Research Programme, Rampur, Chitwan \\ ${ }^{3}$ Agriculture and Food Security Project, Singhdarbar, Plaza, Kathmandu \\ *Corresponding author email: ishwaripu@yahoo.com
}

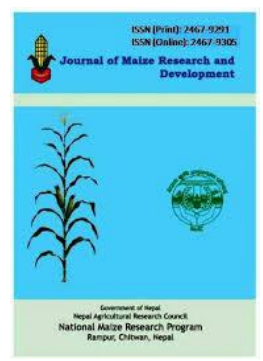

Received: September 2016; Revised: October 2016; Accepted: November 2016

\begin{abstract}
Tillage methods and mulch influences the productivity and water requirement of spring maize hence a field experiment was conducted at the National Maize Research Program, Rampur in spring seasons of 2011 and 2012 with the objectives to evaluate different tillage methods with and without mulch on water requirement and grain yield of spring maize. The experiment was laid out in two factors factorial randomized complete design with three replications. The treatments consisted of tillage methods (Permanent bed, Zero tillage and Conventional tillage) and mulch (with and without). Irrigation timing was fixed as knee high stage, tasseling stage and milking/dough stage. Data on number of plants, number of ears, thousand grain weight and grain yield were recorded and analysed using GenStat. Two years combined result showed that the effect of tillage methods and mulch significant influenced grain yield and water requirement of spring maize. The maize grain yield was the highest in permanent beds with mulch $\left(4626 \mathrm{~kg} \mathrm{ha}^{-}\right.$ ${ }^{1}$ ) followed by zero tillage with mulch $\left(3838 \mathrm{~kg} \mathrm{ha}^{-1}\right)$. Whereas total water applied calculated during the crop period were the highest in conventional tillage without mulch followed by conventional tillage with mulch. The permanent bed with mulch increased the yield and reduced the water requirement of spring maize in Chitwan.
\end{abstract}

Key words: Conventional tillage, permanent beds, spring maize, water requirement, zero tillage

Correct citation: Upadhyay, I.P., Jha, S.K., Karki, T.B., Yadav, J. \& Bhandari, B. (2016). Tillage methods and mulch on water saving and yield of spring maize in Chitwan. Journal of Maize Research and Development, 2 (1): 74-82, doi: http://dx.doi.org/10.3126/jmrd.v2i1.16217

\section{INTRODUCTION}

Tillage and mulch based planting methods can increase efficiencies of the applied inputs, improve soil health, reduce production cost and have exhibited a positive effects on maize yield and show great promise in meeting this challenges (Govaerts et al., 2006). One such raised bed planting is a planting system proposed for maize production in irrigated area of Chitwan, the 
largest maize growing region in Nepal. This system comprises planting maize on the top of raised beds and incorporating plant residue from the previous crop into the soil, which are chopped and left in the field (Limon- Ortega et. al., 2006). Previous studies have shown that raised-bed planting reduces seed mortality rates, increases water- and nitrogen (N)-use efficiency, and improves soil quality (Limon-Ortega et al., 2000). In addition, less labor is required for irrigation and fertilizer is better managed relative to conventional flat planting (Limon-Ortega et al., 2000, 2002). More important, raised-bed planting can reduce crop lodging (crops falling over from high winds and/or heavy rain), while increasing yield by permitting farmers to grow more and superior crops (Govaerts et al., 2006; Wang et al., 2009). Raised bed technology is a land configuration where irrigation water is applied in furrows with plants on the raised beds. The technology increases water application and distribution efficiencies and gives better crop yields. Researchers reported that increase in crop yield is because of higher fertilizer use efficiency, reduced weed infestation, improvement in root proliferation and smaller lodging of the crops. The irrigation water saving depends on size of bed-furrow system where larger bed means lesser number of furrows, less irrigation application time and finally more saving in irrigation water. However, number of beds should meet plant population per unit area and furrows to meet crop water demand and row to row distance of plants (Ahamd et al., 2011). He reviled that grain yield of maize under bed-furrow planting was $19 \%$ higher than the that obtained from traditional practices whereas water application efficiency increased from 50\% to $75 \%$, saving considerable irrigation water as compared to the traditional ridge-furrow irrigation practice. Thus the objective of the study was to determine the growth and productivity of spring maize and water saving under different tillage methods, mulch and their interactions.

\section{MATERIALS AND METHODS}

\section{Experimental Site}

A field experiment was carried out at agronomy experimental farm of National Research Programme (NMRP), Rampur, Chitwan, Nepal located at $27^{\circ} 39^{\prime} \mathrm{N}$ and $84^{\circ} 20^{\prime} \mathrm{E}$ with an altitude of $186 \mathrm{~m}$ above the mean sea level. The experimental farm was well facilitated with irrigation and drainage system.

\section{Soil Type}

Experimental soil was analyzed before the experiment and found as sandy loam texture. The chemical composition of the experimental soil was determined as $2.64 \mathrm{~g} \mathrm{~kg}^{-1}$ of organic matter content. Similarly in an average $30.20 \mathrm{mg} \mathrm{kg}^{-1}$ of available soil Nitrogen (N), $16.90 \mathrm{mg}$ $\mathrm{kg}^{-1}$ of Phosphorous (P) and $109.36 \mathrm{mg} \mathrm{kg}^{-1}$ of Potassium (K) were found with $\mathrm{pH}$ value of 5.51 and Electrical Conductivity (EC) of $251.6 \mu \mathrm{s} \mathrm{cm}^{-1}$.

\section{Tillage and Seeding}

The conventional tillage treatment was tilth with spring tine harrow and leveled before planting for both years after harvest rice. A flat bed of $70 \mathrm{~cm}$ width were constructed as a raised bed with $30 \mathrm{~cm}$ furrow in first year of the experiment and were used for two consecutive years. 
Two rows in one bed were planted at the edges as a permanent bed planting treatment. In the no till treatment the experiment plot were kept in no till condition even for other cropping season and spring maize planted on the same condition without disturbing the soil. The crop before spring maize was harvested from the ground level without leaving any straw in the field for the treatments having no mulch whereas the previous crop (rice) was harvested leaving $30 \mathrm{~cm}$ straw from the ground level for the treatments having mulch. The maize variety Rampur Composite was drilled in early February in both seasons with manual maize planter at spacing of $75 \mathrm{~cm}$ row to row and $20 \mathrm{~cm}$ plant to plant. The total fertilizer applied was $120 \mathrm{~N}, 60 \mathrm{P}_{2} \mathrm{O}_{5}$ and $40 \mathrm{~K}_{2} \mathrm{O} \mathrm{kg}$ $\mathrm{ha}^{-1}$. The nitrogenous fertilizer was top dresses thrice after irrigation.

\section{Crop Management}

Weeding and earthing up were not done. The existing broad leaved weeds was controlled by spraying post emergence herbicide $2,4 \mathrm{D}$ ethyl ester $2.5 \mathrm{ml} / \mathrm{l}$ water. Crop was harvested at the end of April. Data on number of plants, number of ears, thousand grain weight and grain yield were recorded and analyzed using GenStat.

\section{Irrigation Water Use Efficiency}

The irrigation water use efficiency is calculated from the total irrigation amount and the grain yield and is defined by the ratio of grain yield to the total irrigation amount.

$$
I W U E=\left(\frac{G Y}{I}\right) \times 100
$$

Where, IWUE is the irrigation water use efficiency measured as $\mathrm{kg} \mathrm{m}^{-3}, G Y$ is the grain yield measured in ton $\mathrm{ha}^{-1}$ and $I$ is the total irrigation amount required to produce grain yield of one hectare in $\mathrm{mm}$. While calculating the IWUE the grain yield in rainfed has not considered which is being same for all the treatments. The total irrigation amount was calculated as described in equation 2.

\section{Experimental Design}

Two factorial treatments were arranged in RCB design with three replications in which three tillage methods (Conventional, Zero and Permanent Bed) were in factor A whereas mulch (with and without) in factors B. The treatment combinations were as follows:

$$
\begin{array}{ll}
\mathrm{T} 1 & =\text { Permanent bed planting without mulching } \\
\mathrm{T} 2 & \text { = Permanent bed planting with mulching } \\
\mathrm{T} 3 & \text { = Zero tillage without mulching } \\
\mathrm{T} 4 & \text { = Zero tillage with mulching } \\
\mathrm{T} 5 & \text { = Conventional tillage without mulching } \\
\mathrm{T} 6 & \text { = Conventional tillage with mulching }
\end{array}
$$

Three irrigation timing determined for all the treatments were fixed as knee high stage, tasseling stage and milking/dough stage. Time required for irrigating different plots were recorded and total irrigation amount applied were calculated as follows. 


$$
\text { Irrigation Amount }(\mathrm{mm})=\frac{T \times Q}{A}
$$

Where, $\mathrm{T}$ is the times require irrigating each treatment plot in sec, $\mathrm{Q}$ is the discharge of pumps (20 liter per second $=0.02 \mathrm{~m}^{3} \mathrm{sec}^{-1}$ ) and A is the wetted area in $\left(\mathrm{m}^{2}\right)$.

\section{RESULTS AND DISCUSSIONS}

\section{Climate and Crop Water Requirement}

The experimental station falls under the subtropical humid climatic region of Nepal. The annual rainfall of the site was found $1966.7 \mathrm{~mm}$ and $2313.2 \mathrm{~mm}$ in 2011 and 2012 respectively whereas the seasonal rainfall from February to April was found to be $103 \mathrm{~mm}$ and $290.3 \mathrm{~mm}$ for respective cropping season. The temperature of the site varied from $2^{\circ} \mathrm{C}$ to $37.2^{\circ} \mathrm{C}$ in 2011 and $0^{\circ} \mathrm{C}$ to $39.4^{\circ} \mathrm{C}$ in 2012 whereas the average temperature in spring season ranges from $15.9^{\circ} \mathrm{C}$ to $29.4^{\circ} \mathrm{C}$ in 2011 and $11.7^{\circ} \mathrm{C}$ to $27.4^{\circ} \mathrm{C}$ in 2012 . The rainfall and temperature of two cropping season is given in fig. 1.

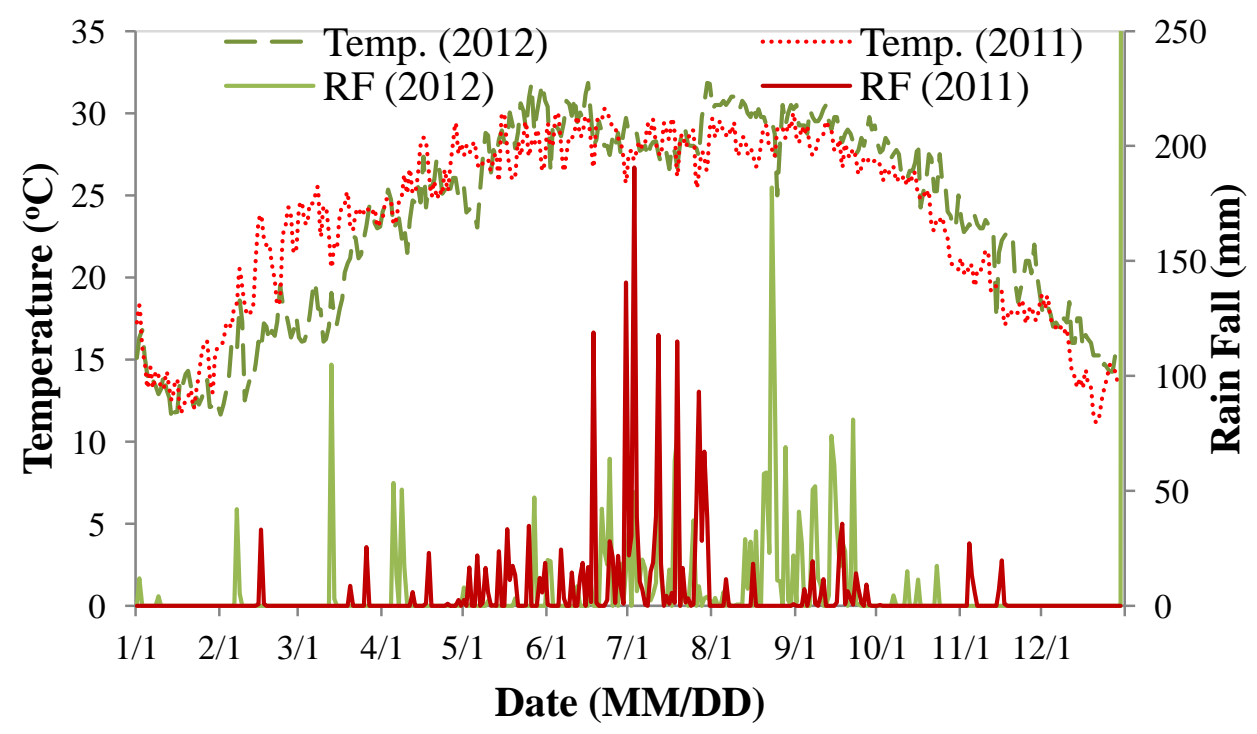

Figure 1. Rainfall and temperature monitored during 2011 and 2012

The Fig. 1 shows that the rainfall was extremely low during spring season for both years this proves that the cultivation of maize in spring requires irrigation water. Bhandari (2012) and Nayava and Gurung (2010) had also reported that about 70 to $90 \%$ of the rainfall occurs during summer monsoon (June to September) and the rest of the month are almost dry. He further reported that the crop water requirement for higher maize yield is $500-600 \mathrm{~mm}$ depending on the climate and crop duration. Chuanyan and Zhongren (2007) had also estimated the total ET of $611.5 \mathrm{~mm}$ for the crop variety of similar duration of Rampur Composite in the arid region of northwest China. This results shows that there is deficit of 300-500 $\mathrm{mm}$ of water to grow spring maize depending on the local weather condition. This is why irrigation requirement for spring 
maize were monitored under different tillage practices to determine minimal irrigation water without reduction of grain yield.

\section{Irrigation Amount and Irrigation Water Use Efficiency}

The total irrigation amount required and the irrigation water use efficiency (IWUE) for individual treatment is presented in Table 1. The irrigation amount in 2011 cropping season is much more than in 2012 cropping season because of very less rainfall in 2011 (Fig 1). The total irrigation amount required for permanent beds with mulching and without mulch was the least (228.3 $\mathrm{mm}$ and $238.2 \mathrm{~mm}$ ) respectively, followed by zero tillage with and without mulching (276.1 $\mathrm{mm}$ and $285.3 \mathrm{~mm}$ ) respectively whereas the irrigation amount for the conventional tillage was found highest $(357.8 \mathrm{~mm})$. The analysis shows that the tillage practices with or without mulching, statistically required same level of irrigation amount. Irrigating in permanent bed and zero tillage fields significantly saved irrigation water. It was found that about 33.42 to $29.57 \%$ of less irrigation water were used in permanent bed as compare to conventional tillage with and without mulch respectively. Similarly in zero tillage treatments with and without mulching saved $20.29 \%$ and $14.79 \%$ of irrigation water compare to conventional tillage with and without mulch respectively. The permanent bed also saved $16.48 \%$ and $17.34 \%$ of irrigation amount compare to zero tillage with and without mulch respectively. The IWUE was found the highest $\left(2.03 \mathrm{~kg} \mathrm{~m}^{-3}\right)$ for permanent bed planting with mulch condition followed by same tillage practice without mulch and were found lowest $\left(0.62 \mathrm{~kg} \mathrm{~m}^{-3}\right)$ for conventional tillage without mulch.

Table 1. Irrigation amount $(\mathrm{mm})$ of individual treatment for corresponding cropping seasons

\begin{tabular}{lcccc}
\hline \multirow{2}{*}{\multicolumn{1}{c}{ Treatment }} & \multicolumn{3}{c}{ Irrigation Amount $(\mathbf{m m})$} & IWUE $\left(\mathbf{k g} / \mathbf{m}^{\mathbf{3}}\right)$ \\
\cline { 2 - 4 } & $\mathbf{2 0 1 0 - 1 1}$ & $\mathbf{2 0 1 1 - 1 2}$ & Combined & \\
\hline PB + No Mulch (T1) & $340.3^{\mathrm{c}} \pm 22$ & $136.1^{\mathrm{c}} \pm 9$ & $238.2^{\mathrm{c}} \pm 16$ & 1.54 \\
PB + Mulch (T2) & $326.1^{\mathrm{c}} \pm 29$ & $130.4^{\mathrm{c}} \pm 12$ & $228.3^{\mathrm{c}^{ \pm}} \pm 21$ & 2.03 \\
ZT + No Mulch (T3) & $407.5^{\mathrm{b}} \pm 23$ & $163.0^{\mathrm{b}} \pm 9$ & $285.3^{\mathrm{b}} \pm 16$ & 1.10 \\
ZT + Mulch (T4) & $394.0^{\mathrm{b}} \pm 19$ & $158.3^{\mathrm{b}} \pm 7$ & $276.1^{\mathrm{b}} \pm 13$ & 1.39 \\
CT + No Mulch (T5) & $511.2^{\mathrm{a}} \pm 13$ & $204.5^{\mathrm{a}} \pm 5$ & $357.8^{\mathrm{a}} \pm 9$ & 0.62 \\
CT + Mulch (T6) & $462.6^{\mathrm{a}} \pm 31$ & $185.6^{\mathrm{a}} \pm 12$ & $324.1^{\mathrm{a}} \pm 22$ & 0.88 \\
$F_{\text {value }}$ & $* *$ & $* *$ & $* *$ & \\
CV $(\%)$ & 2.7 & 2.5 & 2.6 & \\
LSD $_{0.05}$ & 19.82 & 7.52 & 13.7 & \\
\hline
\end{tabular}

** represent significant level, at $\alpha=0.01$. Same letter for mean represent non significance between the treatments at $\alpha=0.05$

The irrigation amount saved in permanent bed has found significant with zero tillage because the irrigation water applied in the furrow irrigate two row adjacent to furrow and do not irrigate the whole bed (about $70 \mathrm{~cm}$ ) whereas in zero tillage the irrigation water spread throughout the field even the infiltration capacity beings low compare to conventional tillage. The IWUE found satisfactory in zero tillage practice compare to permanent bed planting but the conventional tillage practices reduces IWUE drastically. The IWUE between the treatments with and without mulching didn't found significant under the same tillage practices because the 
irrigation amount required in mulching and without mulching condition under the same tillage practices were found non-significant. These findings are in agreement with the findings of Ahmad et al. (1991).

\section{Grain Yield}

Planting methods with or without mulch had significant effect on maize grain yield. Individual years and combined years results on different combinations is presented in Table 2. The treatment T2 recorded the highest grain yield (4626 kg ha $\left.{ }^{-1}\right)$ followed by T4 $\left(3838 \mathrm{~kg} \mathrm{ha}^{-1}\right)$ and T1 (3672 kg ha $\left.{ }^{-1}\right)$ treatments. The treatment T5 had significantly lowest yield $\left(2236 \mathrm{~kg} \mathrm{ha}^{-1}\right)$. Results of this experiment indicated that permanent bed with mulch, zero tillage with mulch and conventional tillage with mulch recorded $25.96 \%, 22.5 \%$ and $27.95 \%$ higher grain yields, respectively as compared to corresponding treatments without mulch. Permanent bed with mulch showed 106.86\% higher grain yield as compared to conventional tillage without mulch. Similarly, T1 and T3 shows $64.22 \%$ and $40.09 \%$ higher grain yield relative to T5 treatments whereas T2 and T4 treatment increases $61.68 \%$ and $34.12 \%$ grain yield compare to T6 treatment. Karki et al. (2015) had found higher grain yield $7012.18 \mathrm{~kg} \mathrm{ha}^{-1}$ in no tillage with residue compare to conventional tillage $\left(6037.59 \mathrm{~kg} \mathrm{ha}^{-1}\right)$. Hammad et al. (2011), had recorded grain yield of $4.67 \mathrm{t} \mathrm{ha}^{-1}$ in combination of 6 number of irrigation with $150 \mathrm{~kg} \mathrm{ha}^{-1}$ fertilizer application.

Table 2. Effects of tillage methods and mulch on grain yield $\left(\mathrm{kg} \mathrm{ha}^{-1}\right)$ of spring maize

\begin{tabular}{|c|c|c|c|}
\hline \multirow{2}{*}{ Treatment } & \multicolumn{3}{|c|}{ Grain Yield (kg ha-1) } \\
\hline & $2010-11$ & 2011-12 & Combined \\
\hline PB + No Mulch (T1) & $3453^{\mathrm{c}} \pm 381$ & $3892^{\mathrm{ab}} \pm 386$ & $3672^{b c} \pm 351$ \\
\hline $\mathrm{PB}+\operatorname{Mulch}(\mathrm{T} 2)$ & $4769^{\mathrm{a}} \pm 249$ & $4483^{\mathrm{a}} \pm 469$ & $4626^{\mathrm{a}} \pm 285$ \\
\hline ZT + No Mulch (T3) & $3174^{\text {cd }} \pm 185$ & $3092^{\mathrm{bc}} \pm 784$ & $3133^{\mathrm{cd}} \pm 484$ \\
\hline $\mathrm{ZT}+\operatorname{Mulch}(\mathrm{T} 4)$ & $3959^{\mathrm{b}} \pm 203$ & $3717^{\mathrm{abc}} \pm 268$ & $3838^{\mathrm{b}} \pm 199$ \\
\hline $\mathrm{CT}+$ No Mulch (T5) & $2642^{\mathrm{e}} \pm 262$ & $1831^{\mathrm{d} \pm 829}$ & $2236^{\mathrm{e}} \pm 499$ \\
\hline $\mathrm{CT}+$ Mulch (T6) & $2827^{\mathrm{de}} \pm 151$ & $2896^{c} \pm 679$ & $2861^{\mathrm{d}} \pm 409$ \\
\hline $\mathrm{F}_{\text {value }}$ & ** & $* *$ & $* *$ \\
\hline $\mathrm{CV}(\%)$ & 6.3 & 14.2 & 8.8 \\
\hline $\mathrm{LSD}_{0.05}$ & 397.4 & 856.5 & 545.8 \\
\hline
\end{tabular}

The result shows that planting spring maize on permanent bed is more beneficial than either planting on no till condition or conventional tillage. Planting with mulch enhance all the productivity significantly. The grain yield in T2 treatment has found highest because of the highest plant population and ear head per hectare along with highest 1000 grain yield as described in the following sections.

\section{Number of Plant and Ear Head}

The plant population and number of ear head per hectare were presented in Table 3 and Table 4 respectively. Both plant density and formation of ear per hectare determine the grain yield. Even the plant density has maintained by gap filling after full germination some plants 
being damaged either by some insects or pest or other environmental factors which may have created because of different tillage practices and consequently differ in irrigation amount applied. It has found that the highest plant population (50374 plant ha ${ }^{-1}$ ) was found in $\mathrm{T} 2$ treatment followed by T1, T4 and T3 in order where the treatments T1, T4 and T3 show same level of plant population. The lowest plant population was found in T6 and T5 treatments. The result coincide with Adhikari et al. (2004), where he get 53,333 plants ha ${ }^{-1}$ under $120 \mathrm{~kg} \mathrm{~N} \mathrm{ha}^{-1}$ and 44,444 plants ha ${ }^{-1}$ for supplied $60 \mathrm{~kg} \mathrm{ha}^{-1}$ of N. Govind et al. (2015) had also recommended the similar pattern for the farmer. The tillage practice not only had affected the plant population but had also affected ear ha ${ }^{-1}$. The result show that the treatments T1, T2 and T4 produce statistically same level of ears ha ${ }^{-1}$ with the highest no 43557 Ears in T2 followed by 40889 Ears in T1. Similarly T3 and T6 treatments give same level of ears ha ${ }^{-1}$ and the lowest numbers 28003 was found in T5 treatment. In this way it has been concluded that the tillage practices had greatly affected the plant population than the number of ears per hectare. The no. of plants and ear head in permanent bed was found highest because the plant receives irrigation from the furrow water which was closer to the maize plant.

Table 3. Effects of tillage methods and mulch on plant per hectare of spring maize

\begin{tabular}{lccc}
\hline \multirow{2}{*}{ Treatment } & \multicolumn{3}{c}{ Plant ha $^{-1}$} \\
\cline { 2 - 4 } & $\mathbf{2 0 1 0 - 1 1}$ & $\mathbf{2 0 1 1 - 1 2}$ & Combined $^{-1}$ \\
\hline PB + No Mulch (T1) & $41481^{\mathrm{bc}} \pm 4896$ & $44444^{\mathrm{b}} \pm 4704$ & $42963^{\mathrm{b}} \pm 4711$ \\
PB + Mulch (T2) & $50673^{\mathrm{a}} \pm 6222$ & $50074^{\mathrm{a}} \pm 5919$ & $50374^{\mathrm{a}} \pm 6050$ \\
ZT + No Mulch (T3) & $39407^{\mathrm{cd}} \pm 4008$ & $39704^{\mathrm{bc}} \pm 4201$ & $39556^{\mathrm{bc} \pm 3875}$ \\
ZT + Mulch (T4) & $44749^{\mathrm{b}} \pm 5420$ & $41481^{\mathrm{bc}} \pm 4201$ & $43115^{\mathrm{b}} \pm 4636$ \\
CT + No Mulch (T5) & $32296^{\mathrm{e}} \pm 7240$ & $32593^{\mathrm{d}} \pm 6552$ & $32444^{\mathrm{d}} \pm 6456$ \\
CT + Mulch (T6) & $36741^{\mathrm{d}} \pm 4201$ & $38519^{\mathrm{c}} \pm 4385$ & $37630^{\mathrm{c}} \pm 3832$ \\
$\mathrm{~F}_{\text {value }}$ & $* *$ & $* *$ & $* *$ \\
CV (\%) & 5.2 & 7.4 & 5.9 \\
LSD $_{0.05}$ & 3864.7 & 5505.1 & 4398.3 \\
\hline
\end{tabular}

Table 4. Effects of tillage and mulch on no of ear per hectare of spring maize

\begin{tabular}{|c|c|c|c|}
\hline \multirow{2}{*}{ Treatment } & \multicolumn{3}{|c|}{ Ear Head ha ${ }^{-1}$} \\
\hline & 2010-11 & 2011-12 & Combined \\
\hline PB + No Mulch (T1) & $39704^{b} \pm 2566$ & $42074^{\mathrm{ab}} \pm 3701$ & $40889^{\mathrm{a}} \pm 3111$ \\
\hline $\mathrm{PB}+\operatorname{Mulch}(\mathrm{T} 2)$ & $43854^{\mathrm{a}} \pm 3585$ & $43259^{a} \pm 3592$ & $43557^{\mathrm{a}} \pm 3552$ \\
\hline $\mathrm{ZT}+\operatorname{No}$ Mulch $(\mathrm{T} 3)$ & $35852^{c} \pm 4385$ & $35556^{\mathrm{bc}} \pm 7901$ & $35704^{\mathrm{b}} \pm 5557$ \\
\hline $\mathrm{ZT}+\operatorname{Mulch}(\mathrm{T} 4)$ & $42073^{\mathrm{ab}} \pm 3702$ & $38519^{\mathrm{abc}} \pm 4474$ & $40296^{\mathrm{a}} \pm 3701$ \\
\hline $\mathrm{CT}+$ No Mulch (T5) & $28153^{\mathrm{e}} \pm 6788$ & $27852^{\mathrm{d}} \pm 6904$ & $28003^{c} \pm 6842$ \\
\hline $\mathrm{CT}+\operatorname{Mulch}(\mathrm{T} 6)$ & $32296^{\mathrm{d}} \pm 5358$ & $33778^{\mathrm{cd}} \pm 7595$ & $33037^{\mathrm{b}} \pm 5302$ \\
\hline $\mathrm{F}_{\text {value }}$ & $* *$ & $* *$ & $* *$ \\
\hline $\mathrm{CV}(\%)$ & 5.0 & 9.7 & 6.1 \\
\hline $\mathrm{LSD}_{0.05}$ & 3362.1 & 6486 & 4099.9 \\
\hline
\end{tabular}

\section{Thousand Grain Weight (TGW)}

The thousand grain weight (TGW) for individual treatments in both cropping season along with the combined years effects is presented in Table 5. The test weight (Thousand Grain 
Weight, TGW) were highly influenced by the tillage practice in combination to mulching. The TGW significantly differ within same tillage practice planted under mulching and without mulching of previous crop. The highest TGW were found in T2 (403.8 g) treatment followed by T1 (364 g) treatment and lowest in T5 (321.9 g) treatment. The Treatments T1 and T4 had found statistically same level of TGW. Similarly, T3 and T6 treatments are also non significant for TGW. Karki et al. (2015) had also recorded highest test weight of $363.94 \mathrm{~g}$ in no till condition with mulching over the conventional tillage.

Table 5. Effects of tillage and mulch on thousand grain weight (g) of spring maize

\begin{tabular}{lccc}
\hline \multirow{2}{*}{ Treatment } & \multicolumn{3}{c}{ Thousand Seeds Weight $(\mathbf{g})$} \\
\cline { 2 - 4 } & $\mathbf{2 0 1 0 - 1 1}$ & $\mathbf{2 0 1 1 - 1 2}$ & Combined \\
\hline PB + No Mulch (T1) & $359.1^{\mathrm{bc}} \pm 5.4$ & $368.9^{\mathrm{b}} \pm 14.1$ & $364.0^{\mathrm{b}} \pm 7.4$ \\
PB + Mulch (T2) & $405.7^{\mathrm{a}} \pm 9.4$ & $402.0^{\mathrm{a}} \pm 7.4$ & $403.8^{\mathrm{a}} \pm 8.0$ \\
ZT + No Mulch (T3) & $351.0^{\mathrm{a} \pm \mathrm{cd}}$ & $345.9^{\mathrm{cd}} \pm 7.6$ & $348.4^{\mathrm{c}} \pm 1.5$ \\
ZT + Mulch (T4) & $368.1^{\mathrm{b}} \pm 5.7$ & $359.1^{\mathrm{bc}} \pm 8.6$ & $363.6^{\mathrm{b}} \pm 6.9$ \\
CT + No Mulch (T5) & $339.8^{\mathrm{e}} \pm 8.6$ & $304.1^{\mathrm{e}} \pm 23.8$ & $321.9^{\mathrm{d}} \pm 8.9$ \\
CT + Mulch (T6) & $347.5^{\mathrm{de}} \pm 6.9$ & $331.0^{\mathrm{d}} \pm 12.9$ & $339.2^{\mathrm{c}} \pm 4.8$ \\
$F_{\text {value }}$ & $* *$ & $* *$ & $* *$ \\
CV (\%) & 1.6 & 3.4 & 2.0 \\
LSD $_{0.05}$ & 10.49 & 21.74 & 12.70 \\
\hline
\end{tabular}

\section{CONCLUSION}

Permanent beds without or with mulch in the form of surface residue saved about 29-33\% irrigation water and increases grain yield by $61 \%$ to $106 \%$ as compared conventional tillage with and without surface residue respectively. Higher yield in permanent bed and zero tillage with mulch was due to improved irrigation water use efficiency, the higher plant density with highest cob numbers per unit area and significantly higher 1000 grain weight.

\section{ACKNOWLEDGEMENTS}

The authors are grateful to Dr D.B. Gurung, former Maize Coordinator, NMRP and former Executive Director, NARC for his encouragement and full support to carry out this experiment at NMRP, Rampur. Thanks are due to Mr D.B. Gurung, Mechanic and Mr. A.B. Tamang, Tractor Operator, NMRP, Rampur for their help in repairing and operating different tractor drawn planter and manual planter in the field.

\section{REFERENCES}

Adhikari, B. H., Sherchan, D. P., \& Neupane, D. D. (2004). Effects of nitrogen levels on the production of maize (Zea mays L.) planted at varying densities in Chitwan valley. In Proc. of the 24th National Summer Crops Research Workshop in Maize Research and Production in Nepal.

Ahamd, R. N., Arshad, M., \& Shahid, M. A. (2011, October). Raised bed technology for crop water productivity of maize and cotton. In Proc ICID 21 st International Congress on Irrigation and Drainage. pp. 15-23. 
Bhandari, G. (2012). Estimation of Potential evapotranspiration and crop coefficient of maize at Rupandehi district of Nepal. International Journal of Agriculture Management Development, 2(4), 285-293.

Chuanyan, Z. H. A. O., \& Zhongren, N. A. N. (2007). Estimating water needs of maize (Zea mays L.) using the dual crop coefficient method in the arid region of northwestern China. African Journal of Agricultural Research, 2(7), 325-333.

Govaerts, B., Sayre, K. D., Ceballos-Ramirez, J. M., Luna-Guido, M. L., Limon-Ortega, A., Deckers, J., \& Dendooven, L. (2006). Conventionally tilled and permanent raised beds with different crop residue management: effects on soil C and N dynamics. Plant and Soil, 280(12), 143-155.

Govind, K. C., Karki, T. B., Shrestha, J., \& Achhami, B. B. (2015). Status and prospects of maize research in Nepal. Journal of Maize Research and Development, 1(1), 1-9.

Hammad, H. M., Ahmad, A., Azhar, F., Khaliq, T., Wajid, A., Nasim, W., \& Farhad, W. (2011). Optimizing water and nitrogen requirement in maize (Zea mays L.) under semiarid conditions of Pakistan. Pakistan Journal of Botany, 43(6), 2919-2923.

Karki, T. B., Govind, K. C., Shrestha, J., \& Jadav, J. P. (2015). Tillage and planting density affect the performance of maize hybrids in Chitwan, Nepal. Journal of Maize Research and Development, 1(1), 10-20.

Limon-Ortega, A., Sayre, K. D., \& Francis, C. A. (2000). Wheat nitrogen use efficiency in a bed planting system in northwest Mexico. Agronomy Journal, 92(2), 303-308.

Limon-Ortega, A., Sayre, K. D., Drijber, R. A., \& Francis, C. A. (2002). Soil attributes in a furrow-irrigated bed planting system in northwest Mexico. Soil and Tillage Research, 63(3), 123-132.

Limon-Ortega, A., Govaerts, B., Deckers, J., \& Sayre, K. D. (2006). Soil aggregate and microbial biomass in a permanent bed wheat-maize planting system after 12 years. Field Crops Research, 97(2), 302-309.

Nayava, J. L. \& Gurung, D. (2010). Impact of climate change on production and productivity: A case study of maize research and development in Nepal. Journal of Agriculture and Environment, 11, 59-69.

Wang, F., He, Z., Sayre, K., Li, S., Si, J., Feng, B., \& Kong, L. (2009). Wheat cropping systems and technologies in China. Field Crops Research, 111(3), 181-188. 